\title{
Systemic arterial hypertension, blood pressure levels and associated factors in schoolchildren
}

\author{
Priscila Heleno ${ }^{1}$, Luciana Emerick ${ }^{1}$, Nicole Mourão ${ }^{1}$, Diego Pereira ${ }^{1}$, Isabela Santos ${ }^{1}$, Ana Sophia de Oliveira ${ }^{1}$, \\ luana Santos ${ }^{2}$, Wendell Bila ${ }^{3 *}$, Márcia Christina Romano ${ }^{4}$, Joel Lamounier ${ }^{5}$ \\ ${ }^{1}$ MD. Medical diploma from Universidade Federal de São João del-Rei, Campus Centro-Oeste (UFSJ-CCO), Divinópolis, MG, Brazil \\ ${ }^{2}$ Nurse. Nursing diploma from UFSJ-CCO, Divinópolis, MG, Brazil \\ ${ }^{3}$ Physical Educator. PhD Student, Health Science Program, UFSJ-CCO, Divinópolis, MG, Brazil \\ ${ }^{4}$ Nurse. PhD in Nursing. Adjunct Professor in the Nursing Program, UFSJ-CCO, Divinópolis, MG, Brazil \\ ${ }^{5} \mathrm{MD}$. PhD in Public Health and Nutrition. Full Professor of the Pediatrics Department, UFSJ, São João del-Rei, MG, Brazil
}

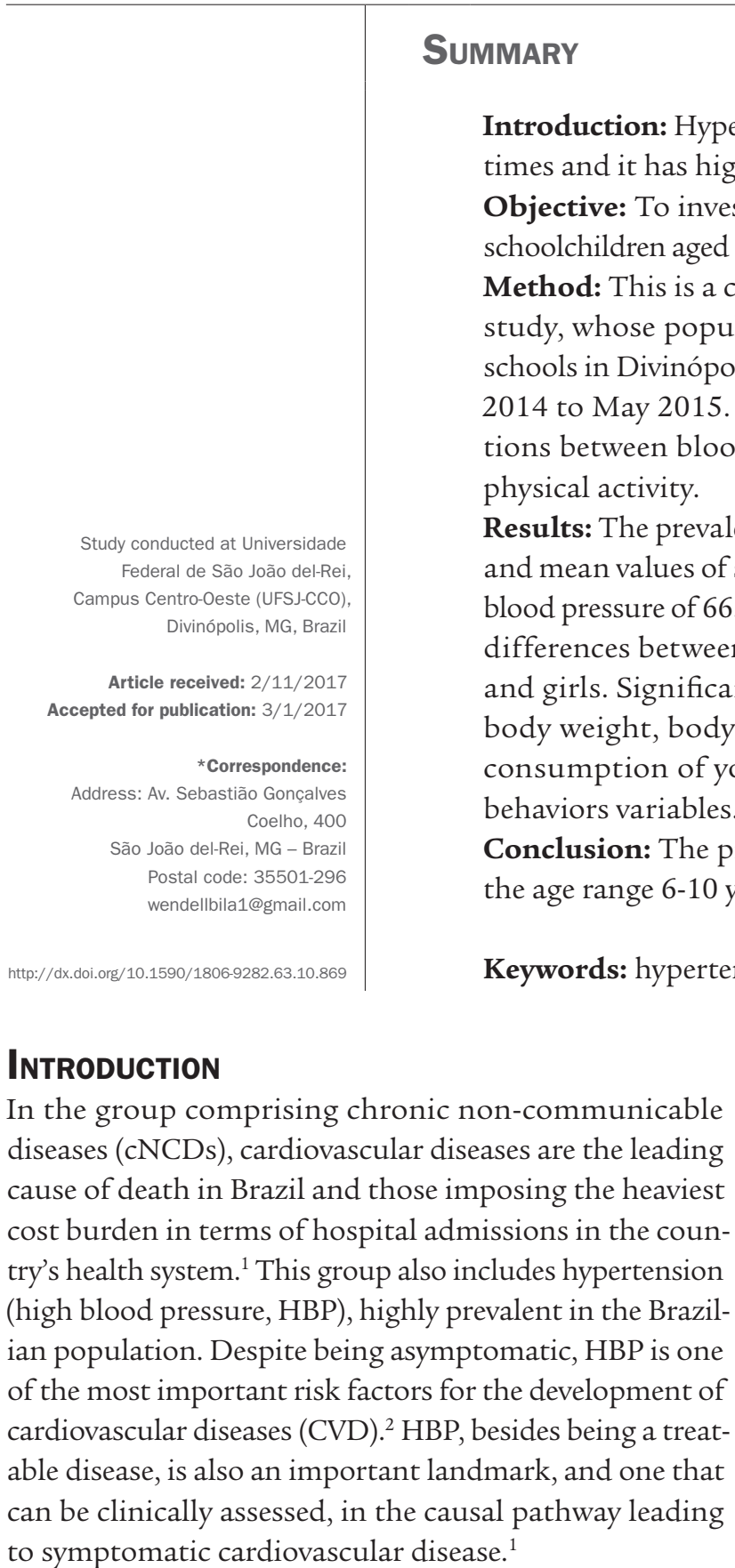

According to the $7^{\text {th }}$ Brazilian Guideline on Hypertension, published in 2016 by the Brazilian Society of Cardiology, hypertension is defined as a multifactorial clinical condition characterized by high and sustained blood pressure levels. ${ }^{3}$ It is estimated that 7.1 million people die annually worldwide due to HBP and that $4.5 \%$ of diseases are attributed to it. ${ }^{4}$

Thus, in Brazil, HBP is an important public health issue. ${ }^{4}$ However, there is not a single cause for this disease, but several risk factors instead that increase the likelihood of its occurrence. ${ }^{5}$ Its prevalence is high and increases at older age. ${ }^{6}$

Epidemiological studies on high blood pressure in children have been a source of consistent evidence that a high 
percentage of essential arterial hypertension cases in adults initiate in childhood. ${ }^{7}$ Its early recognition in childhood and adolescence is therefore critical for the prevention of various cardiovascular, renal and neurological complications. ${ }^{5,6}$

The prevalence of HBP, according to the Brazilian Society of Hypertension, varies from 22.3 to $43.9 \%$ in the adult population and, in children and adolescents, from 12 to $17 \%{ }^{8}$ This variation in the findings can possibly be explained due to the diversity in the number of methodologies used (and in the number of measurements as well), age groups chosen, number of visits performed and total follow-up time. ${ }^{7}$

Thus, due to the importance of HBP for public health and the need to improve knowledge about it, especially when it affects children, this study investigates the status of HBP among schoolchildren aged 6 to 10 years and factors associated with blood pressure levels in the municipality of Divinópolis, in the midwest of the state of Minas Gerais, Brazil.

\section{Method}

This is an epidemiological, observational, cross-sectional and population-based study, in which prevalence of HBP and associated risk factors were analyzed in children aged 6 to 10 years enrolled in municipal public schools in Divinópolis, Minas Gerais, Brazil, and randomly selected in order to obtain a sample of this population.

For initially calculating a simple, random sample, the number of eligible schools was considered, as were their respective distributions of students across classrooms and school grades/years when drawing the students by lot. The prevalence of high blood pressure, as estimated according to the $6^{\text {th }}$ Guideline on Hypertension, was 2 to $13 \%,{ }^{3}$ with a confidence limit of $4 \%$, design effect 1 . The public domain statistics software package OpenEpi was used in the calculations (available from http://www.openepi.com/Menu/OE_Menu.htm).

A universe of 6,030 students aged 6-10 years was used, and those duly enrolled in the 35 municipal public system schools were included as the eligible population, according to data provided by the Municipal Department of Education of Divinópolis, Minas Gerais, Brazil. Schools that did not have any students enrolled in at least two grades/years or those with fewer than 15 students enrolled in at least two grades/years could not participate in the study. Of the 27 schools remaining, 16 were drawn by lot. As per the calculated sample size, 260 participants would be required in order for the study to be appropriately conducted. A total of 284 students who consented to participate were included in the study, of whom 132 were boys and 152 were girls, and from whom data to be used in the study was collected.

This age group (between 6 and 10 years) corresponds to an important time window that is well suited for capturing the way children begin to develop their personal habits - it is a moment in time at which children shape their aesthetic preferences and patterns as mediated by the media and by their social experiences with other children; since they spend much of their time at school, this expands their repertoire of habits, which they had previously learned from their families only. ${ }^{9}$

The students' parents/guardians were informed about the study by means of a school memo. Participation only occurred after both parents/guardians and child (at the time of data collection) had signed the respective free and informed consent forms (FICF). Children not belonging to the age group 6-10 years or previously diagnosed with secondary HBP, cardiovascular disease or renal insufficiency, or those who had not signed the FICF (or whose parents/ guardians had not signed it), were excluded from the study.

Data collection in schools was preceded by a previous step aimed at clarifying to school directors and teachers the study objectives and procedures to be carried out. The study was conducted in compliance with the guidelines contained in Resolution 466/12 of the National Health Council of the Brazilian Ministry of Health and approved by the Research Ethics Committee at Universidade Federal de São João del Rei-UFSJ (CAAE 25332213.7.0000.5545).

Data collection was performed in the period from October 2014 to May 2015 by a previously trained team. The children responded to the questionnaires, underwent an anthropometric assessment, and had their blood pressure measured, all of which followed standardized procedures. ${ }^{10-12}$ All anthropometric parameters (weight, height, waist circumference), in addition to triceps and calf skin folds, were measured in triplicates, and the results were expressed as the means obtained, all of which were coded and stored with the aid of an SPSS statistical software, version 20.0 for Windows, which was used in the statistical analyses. Body mass index (BMI) and its respective $z$-scores were calculated, as was the percentage of body fat (\%BF), according to the equation proposed by Slaughter et al. in $1988 .{ }^{13}$

Questionnaires with information relative to high blood pressure and its risk factors were administered to and answered by the children's parents and/or guardians. The instruments used are the following:

- Socioeconomic questionnaire: by the Brazilian Association of Population Studies (ABEP) of 2014, ${ }^{14}$ and classifications according to scores ranging from 0 to 
100 points, yielding stratifications into classes A, B1, B2, C1, C2, D and E.

- Eating habits: questionnaire on dietary frequency, developed by del Pino, ${ }^{15}$ in 2009 . The evaluation was made considering the foods chosen for each daily meal.

- Quality of life: information on the children's perception of their satisfaction with daily activities, gathered with the AUQUEL questionnaire, presented by Manificat and Dazord ${ }^{16}$ in 2002, in which the satisfaction phases were presented by using four aspects expressing a child's different preferential conditions.

- Physical activity: the Netherlands Physical Activity Questionnaire (NPAQ) questionnaire. ${ }^{17}$ The level of physical activity was assessed as a continuous variable.

Systemic blood pressure was measured by using an oscillometric method with an OMRON HEM-705CP automatic device, validated for research purposes, verified and approved by Inmetro and the Brazilian Society of Cardiology, coupled to a child's armband, with a circumference of $10-22 \mathrm{~cm}$, in one single visit. The first measurement was performed five minutes after the child had assumed a sitting position, and two minutes subsequent to that, between the two other measurements. The arithmetic mean of the measured values was used.

The descriptive results were obtained by means of the measures of central tendency (mean and median) and dispersion (standard deviation and interquartile range).

The prevalence of high blood pressure was estimated in each age group by gender, age and height percentiles, according to the guidelines set in 2009 by the World Health Organization (WHO) and the $7^{\text {th }}$ Brazilian Guide- line on Hypertension. ${ }^{3,18} \mathrm{HBP}$ values were then compared with the associated variables by using multivariate linear and logistic analyses. Comparisons of systolic and diastolic blood pressures, as well as BMI, \%BF, and waist circumference (WC) were drawn between the genders by using Student's t-test or Mann-Whitney test, according to the normality of the data. A level of significance $\alpha=5 \%$ was used.

\section{Results}

The mean age of the sample was $8.2( \pm 1.4)$ years, with $53.5 \%$ of participants being females and a total of $67.5 \%$ belonging to classes $\mathrm{C}, \mathrm{D}$ and $\mathrm{E}$. The description of the remaining variables in the study can be seen in Table 1 . The SBP in boys was $101.9( \pm 14.2) \mathrm{mmHg}$ and $101.6( \pm 12.3)$ $\mathrm{mmHg}$ in girls. The mean DBP was $65.4( \pm 12.1) \mathrm{mmHg}$ and $66.5( \pm 10.5) \mathrm{mmHg}$ for boys and girls, respectively.

The prevalence of high blood pressure was found to be 15.2\% (classified as stages 1 and 2), as described in Table 2.

\%BF means differed significantly between genders: 24.2 and $26.2 \%$ body fat, respectively, for boys and girls.

The multivariate linear regression analysis, adjusted for gender and age, showed significant associations $(\mathrm{p}<0.05)$ between high blood pressure $($ SBPmean $=101.7$ $\mathrm{mmHg}$, DBPmean $=66.0 \mathrm{mmHg}$ ), weight z-score, BMI Z-score, cardiovascular risk according to $\mathrm{WC},{ }^{19,20}$ excess weight according to the $\% \mathrm{BF}, 21,22$ consumption of beef/ chicken, beans, yogurt and some behavioral variables, as described in Table 3.

The logistic regression analysis, also adjusted for gender and age, showed significant associations $(\mathrm{p}<0.05)$ between elevated HBP levels (hypertension stages 1 or 2), and weight $\mathrm{z}$-score, BMI z-score, cardiovascular risk ac-

TABLE 1 Anthropometric, socioeconomic and physical activity variables evaluated in schoolchildren aged 6 to 10 years in the city of Divinópolis, MG, 2015. $n=284$.

\begin{tabular}{|c|c|c|c|c|c|}
\hline & $\begin{array}{l}\text { n } \\
\text { Sample }\end{array}$ & Mean & Standard deviation & Median & IQR \\
\hline $\mathrm{SBP}(\mathrm{mmHg})$ & 283 & 101.7 & 13.2 & 100.0 & $92.3-111.0$ \\
\hline $\mathrm{DBP}(\mathrm{mmHg})$ & 283 & 66.0 & 11.2 & 64.0 & $58.3-71.7$ \\
\hline Weight (kg) & 284 & 31.2 & 9.5 & 29.3 & $24.4-35.4$ \\
\hline Height (cm) & 284 & 132.9 & 10.4 & 133.0 & $125.5-141.0$ \\
\hline BMI $\left(\mathrm{kg} / \mathrm{cm}^{2}\right)$ & 284 & 17.4 & 3.3 & 16.5 & $15.1-18.8$ \\
\hline $\mathrm{WC}(\mathrm{cm})$ & 284 & 59.5 & 8.3 & 56.7 & $54-63.4$ \\
\hline$\% B F$ & 284 & 25.2 & 8.6 & 23.8 & $19.1-30.7$ \\
\hline Level of physical activity* & 195 & 1.6 & 0.7 & 1.6 & $1.3-2.1$ \\
\hline Number of hours spent in front of a TV, computer, etc. & 243 & 3.0 & 1.7 & 3.0 & $2.0-4.0$ \\
\hline Socioeconomic level** & 277 & 19.2 & 6.6 & 19.0 & $16-24$ \\
\hline
\end{tabular}

SBP: systolic blood pressure; DBP: diastolic blood pressure; WC: waist circumference; BMI: body mass index; \%BF: percentage of body fat; IQR: interquartile range. ${ }^{*}$ According to the NPAQ questionnaire, ${ }^{17}$ on a scale of $1-5$ points.

${ }^{* *}$ According to the ABEP questionnaire. ${ }^{14}$ 
TABLE 2 Prevalence of high blood pressure among the school children in the study, Divinópolis, MG, Brazil, 2015. n=283.

\begin{tabular}{llll} 
BP classification & N & \% & Percentages* \\
\hline Normal & 213 & 75.3 & $<90$ \\
\hline Pre-hypertension & 27 & 9.5 & $\geq 90$ and $<95$ \\
\hline HBP stage 1 & 35 & 12.4 & $\geq 95$ and $<99+5 \mathrm{mmHg}$ \\
\hline HBP stage 2 & 08 & 2.8 & $>$ Stage 1 \\
\hline Total & 283 & 100 & \\
\hline
\end{tabular}

BP: blood pressure; $\mathrm{N}$ : number of subjects.

*According to the $7^{\text {th }}$ Guideline on Hypertension. ${ }^{3}$

TABLE 3 Final multivariate and logistic linear regression model of blood pressure levels among schoolchildren aged 6 to 10 years, Divinópolis, MG, and significantly associated variables ${ }^{\ddagger} . \mathbf{n}=284$.

\begin{tabular}{|c|c|c|c|}
\hline Variable & $\beta$ & $\mathrm{Cl}$ & p-value \\
\hline \multicolumn{4}{|l|}{ Linear regression } \\
\hline \multicolumn{4}{|l|}{ SBP } \\
\hline z-score weight & 0.417 & 2.6 to 4.9 & $<0.05$ \\
\hline z-score BMI & 0.410 & 2.7 to 4.6 & $<0.05$ \\
\hline CVR-WC (Bergman 2010, Sant 2009) & 0.373 & 7.9 to 14.5 & $<0.05$ \\
\hline Consumption of yogurt* & 0.162 & 0.7 to 5.1 & 0.007 \\
\hline Sports practice $^{\circ}$ & 0.141 & 0.5 to 6.1 & 0.023 \\
\hline Sleeping away from home ${ }^{\circ}$ & 0.136 & 0.5 to 4.5 & 0.024 \\
\hline \multicolumn{4}{|l|}{ DBP } \\
\hline z-score weight & 0.354 & 1.7 to 3.7 & $<0.05$ \\
\hline z-score BMI & 0.333 & 1.7 to 3.4 & $<0.05$ \\
\hline Excess weight, based on \%BF & 0.123 & 0.1 to 5.5 & $<0.05$ \\
\hline CVR-WC & 0.330 & 5.6 to 11.3 & $<0.05$ \\
\hline Consumption of beans* & -0.118 & -3.6 to 0.0 & 0.049 \\
\hline Consumption of beef/chicken* & -0.124 & -3.9 to -0.3 & 0.038 \\
\hline \multicolumn{4}{|l|}{ Logistic regression** } \\
\hline z-score weight & 0.663 & 0.5 to 0.9 & 0.020 \\
\hline z-score BMI & 0.607 & 0.5 to 0.8 & $<0.05$ \\
\hline CVR-WC & 0.243 & 0.1 to 0.5 & $<0.05$ \\
\hline Hours in front of a screen & 0.816 & 0.7 to 0.9 & 0.044 \\
\hline Consumption of yogurt* & 0.584 & 0.4 to 0.9 & 0.011 \\
\hline Consumption of pizza and sandwiches* & 0.536 & 0.3 to 0.9 & 0.033 \\
\hline
\end{tabular}

SBP: systolic blood pressure; DBP: diastolic blood pressure; BMI: body mass index; \%BF: percentage of body fat; CVR-WC: cardiovascular risk based on waist circumference; $\beta$ : level of association; $\mathrm{Cl}$ : confidence interval.

‡ Significant, at a significance level of 0.05

* According to the presence of the food item in each daily meal.

- Levels of satisfaction pointed out based on the visualization of smiley faces (from the saddest to the most cheerful).

**Associations between the presence of abnormal blood pressure levels (stages 1 or 2 ) and other variables.

cording to WC, amount of screen hours, consumption of yogurt, pizza and sandwiches (Table 3).

\section{Discussion}

The $15.2 \%$ prevalence of high blood pressure found in our study was higher than the $9.6 \%$ demonstrated by Bloch et al. ${ }^{23}$ in their ERICA study (Study of Cardiovascular Risk Factors in Adolescents) with Brazilian adolescent students in 2016, and also higher than the $13.8 \%$ found by Costanzi et al. ${ }^{24}$ in 2009, who evaluated children aged 7-12 years from Caxias do Sul, in the state of Rio Grande do Sul, as well as other studies. ${ }^{25,26}$ Nevertheless, the HBP range found in our study was within the variation between 2 and 13\% described by Gomes and Alves ${ }^{27}$ in 2009, in their study with high school students in the State of Pernambuco, Brazil. However, HBP prevalence proved to be slightly 
below $16.6 \%$ when using the first measurement, as demonstrated by Rezende et al. in 2003 among schoolchildren aged 7-14 years in Barbacena, in the state of Minas Gerais. ${ }^{28}$

The prevalence of pre-hypertensive individuals found in our study was also lower than the $14.5 \%$ reported by Bloch et al. ${ }^{23}$

The Brazilian Society of Cardiology highlights instances in which the prevalence of pre-hypertension was $12-17 \%$, in single measurements, especially in overweight and obese adolescents, ${ }^{8}$ a value that was higher than that found in the present study for borderline BP, which was $9.5 \%$.

There were no statistically significant differences in $\mathrm{BP}$ values between boys and girls, similarly to the findings published by Ferreira and Aydós, ${ }^{25}$ in 2010, who did not find significant differences in pressure levels between genders either.

Obesity is probably the leading associated condition for primary arterial hypertension in children and adolescents, accounting for more than half the risk of developing HBP. Diet, physical exercise and weight loss are cited as important factors for lifestyle changes. ${ }^{8}$ In this context, $\% \mathrm{BF}$ showed significant differences between genders, thus confirming the already well-established knowledge of the largest fat component in girls.

Brazilian studies published by Queiroz et al., ${ }^{26}$ in 2008, Nogueira et al., ${ }^{29}$ in 2007, and Crispin et al., ${ }^{30}$ in 2014, showed a positive association between BMI and increased blood pressure. An American study also attributed altered BP levels to a high prevalence of overweight among children and adolescents. ${ }^{31}$ This possibly corroborates the positive associations in the present study between blood pressure levels and weight z-score, $\mathrm{BMI} z$-score, overweight according to \% $\mathrm{BF}$ and cardiovascular risk according to $\mathrm{WC}$, indicators known to be associated with cardiovascular diseases.

The positive associations found between blood pressure levels and waist circumference are corroborated by the findings of Costanzi et al., ${ }^{24} 2009$, showing that children with an increased WC were 2.8 times more likely to have HBP. Despite the fact that this same study showed that individuals with high scores in the National Economic Index are 2.6 times more likely to have HBP, we failed to find significant associations between these variables, a result that was not obtained in the study by Rosaneli et al., ${ }^{32}$ in 2013, either.

There were other significant and positive associations between variables and BP levels, such as consumption of yogurt, pizzas and sandwiches, but there were also other negative associations, such as consumption of beans and beef/chicken. In Brazil, the Ministry of Health ${ }^{33}$ states that animal foods are good sources of protein and most of the vitamins and minerals we need; still, they have characteristics that may favor the risk of obesity, heart disease, and other chronic diseases. Animal foods can also contain cholesterol, which can build up in blood vessels, thereby contributing to an increased risk of heart diseases. The document goes on to recommend three servings of milk and dairy products per day.

Even though breastfeeding time was not assessed in the present study, children who are breastfed for less than six months are known to be more prone to have HBP as compared to those who were breastfed for a longer period, which thus suggests a protective effect of breastfeeding against HBP in this population. ${ }^{34}$ Furthermore, birth weight is known to be associated with the appearance of cNCDs, such as obesity and diabetes, according to the conclusions in the studies conducted by Jornayvaz et al., ${ }^{35}$ and $\mathrm{Yu}$ et al. ${ }^{36}$

Because this is a study with an observational and cross-sectional design, its cause-and-effect analysis is limited. Additionally, one must bear in mind the recommendation of taking blood pressure measurements in more than one visit in order to confirm the diagnosis of high blood pressure.

The students' individual results - namely blood pressure levels, nutritional profile (BMI) and appropriate recommendations for further referral in order to confirm possible diagnoses of high blood pressure - were addressed, sealed and sent to school directors, in writing, so that the information could be conveyed to the children's parents/guardians.

\section{Conclusion}

The data displayed in our study reveal important aspects regarding the profile of schoolchildren aged 6-10 years, especially in terms of blood pressure behavior. It is an important stage in the development of children as far as the formation of life habits is concerned. The results offer valuable academic information on monitoring during this period of time, which is crucial for the children's growth and development and can be used to educate the population about health issues.

\section{Resumo}

Hipertensão arterial, níveis pressóricos e fatores associados em escolares

Introdução: A hipertensão arterial sistêmica representa um importante problema de saúde pública na contemporaneidade, pois tem alta prevalência em todo o mundo. 
Objetivo: Investigar a situação da hipertensão arterial sistêmica em escolares de 6 a 10 anos no município de Divinópolis, MG, Brasil e fatores associados.

Método: Este estudo tem caráter epidemiológico de corte transversal, descritivo e analítico, cuja população foi de crianças de 6 a 10 anos matriculadas em escolas públicas municipais de Divinópolis, MG, Brasil. A coleta dos dados foi realizada no período de outubro de 2014 a maio de 2015. Regressões lineares e logísticas multivariadas foram utilizadas para testar associações entre pressão arterial, variáveis socioeconômicas, antropométricas, alimentares e atividade física.

Resultados: A prevalência de hipertensão arterial foi de $15,2 \%$ em uma amostra de 284 crianças, cujos dados forneceram valores médio de pressão arterial sistólica de 101,7 $( \pm 13,2) \mathrm{mmHg}$ e de pressão arterial diastólica de $66,0( \pm 11,2)$ $\mathrm{mmHg}$. O percentual de gordura corporal apresentou diferenças significativas entre os sexos, sendo $24,2 \%$ e $26,2 \%$ de gordura corporal, respectivamente, para meninos e meninas. Foram encontradas associações significativas entre níveis pressóricos, peso corporal, índice de massa corporal, circunferência de cintura, percentual de gordura corporal, consumo de iogurte, carne bovina/frango, feijão, iogurte, pizzas, sanduíches e algumas variáveis comportamentais.

Conclusão: Os dados apresentados revelam aspectos importantes relativos ao perfil de escolares na faixa etária de 6 a 10 anos, especialmente relacionados ao comportamento da pressão arterial.

Palavras-chave: hipertensão, criança, prevalência, obesidade, epidemiologia.

\section{References}

1. Schmidt MI, Duncan BB, Silva GA, Menezes AM, Monteiro CA Barreto SM. Doenças crônicas não transmissíveis no Brasil: carga e desafios atuais. Saúde no Brasil 4 [Internet]. 2011 [cited 2014 Apr 21]. Available from: http://dms. ufpel.edu.br/ares/bitstream/handle/123456789/222/1\%20\%202011\%20 Doen\%C3\%A7as\%20cr\%C3\%B4nicas\%20n\%C3\%A3o\%20 transmiss\%C3\%ADveis $\% 20$ no\%20Brasil.pdf?sequence $=1$.

2. World Health Organization. Global atlas on cardiovascular disease prevention and control [Internet]. Geneva: World Health Organization; 2011 [cited 2014 Apr 21]. Available from: http://www.who.int/cardiovascular_diseases/ publications/atlas_cvd/en/.

3. Malachias MVB, Souza WKSB, Plavnik FL, Rodrigues CIS, Brandão AA, Neves MFT, et al. $7^{a}$ Diretriz Brasileira de Hipertensão. Arq Bras Cardiol. 2016; 107(3 Suppl 3):1-83.

4. Boing AC, Boing AF. Hipertensão arterial sistêmica: o que nos dizem os sistemas brasileiros de cadastramentos e informações em saúde. Rev Bras Hipertens. 2007; 14(2):84-8.

5. Brasil. Ministério da saúde. Secretaria de Políticas de Saúde. Departamento de Ações Programáticas Estratégicas. Plano de reorganização da atenção à hipertensão arterial e ao diabetes mellitus. Manual de hipertensão arterial e diabetes mellitus [Internet]. 2002 [cited 2016 Apr 21]. Available from: http://dab.saude.gov.br/docs/publicacoes/geral/miolo2002.pdf.
6. Brasil.Ministério da Saúde. Secretaria de vigilância em saúde. Vigitel Brasil 2009. Vigilância de fatores de risco e proteção para doenças crônicas por inquérito telefônico [Internet]. 2010 [cited 2016 Apr 21]. Available from: http://www.abeso.org.br/uploads/downloads/75/553a24c01eb80.pdf.

7. Medeiros CCM, Xavier IS, Santos VEFA, Souza MAO, Vasconcelos AS, Alves ERP. Obesidade infantil como fator de risco para hipertensão arterial: uma revisão integrativa. REME. 2012; 16(1):111-9.

8. Simão AF, Precoma DB, Andrade JP, Correa Filho H, Saraiva JFK, Oliveira GMM, et al. I Diretriz Brasileira de Prevenção Cardiovascular. Arq Bras Cardiol. 2013; 101(Suppl 2):1-62.

9. Bila WC. Comparação do método de diluição do óxido de deutério (D2O) com protocolos clássicos de avaliação e composição corporal em escolares de 6 a 9 anos com sobrepeso e obesidade [dissertation]. Divinópolis: Programa de Pós graduação em Ciências da Saúde, Universidade Federal de São João del-Rei; 2014.

10. Jelliffe DB. Evaluación del estado de nutrición de la comunidad. Geneva: World Health Organization; 1968 [cited 2014 Apr 21]. Available from: apps. who.int/iris/bitstream/10665/41408/1/9243400533_spa.pdf.

11. Organização Mundial de Saúde. Curvas de crescimento 2006-2007 [Internet] 2007 [cited 2016 Apr 21]. Available from: http://www.abeso.org.br/pagina/393/ curvas-de-crescimento-da-oms-de-2006-e 2007\%C2\%A0.shtml. 2006-2007.

12. Sociedade Brasileira de Hipertensão. VI Diretrizes Brasileiras de Hipertensão. Rev Bras Hipertens. 2010; 95(1 Suppl.1): 1-51.

13. Slaughter MH, Lohman TG, Boileau RA, Horswill CA, Stillman RJ, Van Loan MD, et al. Skinfold equations for estimations of body fatness in children and youth. Hum Biol. 1988; 60(5):709-23.

14. Associação Brasileira de Estudos em Pesquisa. Critério padrão de classificação econômica Brasil 2012 [Internet]. 2014 [cited 2014 Apr 21]. Available from: http://www.abep.org/criterio-brasil.

15. del Pino DL. Adaptação e validação de um questionário de freqüência alimentar para crianças de 6 a 10 anos [dissertation]. Porto Alegre: Faculdade de Medicina. Programa de Pós-Graduação em Ciências Médicas: Endocrinologia, Universidade Federal do Rio Grande do Sul; 2009.

16. Manificat S, Dazord A. [Child and adolescent quality of life: study analysis] Rech Soins Infirm. 2002; (70):13-22.

17. Bielemann RM, Reichert FF, Paniz VM, Gigante DP. Validation of the Netherlands physical activity questionnaire in Brazilian children. Int J Behav Nutr Phys Act. 2011; 8:45

18. World Health Organization. Growth reference: height for age (5-19 years) [Internet]. 2009 [cited 2014 Apr 21]. Available from: http://www.who.int/ growthref/who2007_height_for_age/en/index.html.

19. Sant'Anna MS, Tinoco AL, Rosado LE, Sant'Ana LF, Mello AC, Brito IS, et al. Body fat assessment by bioelectrical impedance and its correlation with different anatomical sites used in the measurement of waist circumference in children. J Pediatr (Rio J). 2009; 85(1):61-6.

20. Bergmann GG, Gaya A, Halpern R, Bergmann ML, Rech RR, Constanzi CB, et al. [Waist circumference as screening instrument for cardiovascular disease risk factors in schoolchildren]. J Pediatr (Rio J). 2010; 86(5):411-6.

21. Lohman TG. Measuring body fat using skinfolds. Champaigns: Human Kinetics; 1987.

22. Lohman TG, Roche AF, Martoreli R. Anthropometric standartization reference manual. Champaigns: Human Kinectics; 1988.

23. Bloch KV, Klein CH, Szklo M, Kuschnir MCC, Abreu GA, Barufaldi LA, et al. ERICA: prevalences of hypertension and obesity in Brazilian adolescents. Rev Saude Publica. 2016; 50(Suppl 1):1s-12s.

24. Costanzi CB, Halpern R, Rech RR, Bergmann MLA, Alli LR, Mattos AP. Associated factors in high blood pressure among schoolchildren in a middle size city, southern Brazil. J Pediatr (Rio J). 2009; 85(4):335-40.

25. Ferreira JS, Aydos RD. Prevalência de hipertensão arterial em crianças e adolescentes obesos. Cienc Saude Coletiva. 2010; 15(1):97-104.

26. Queiroz VM, Moreira PVL, Vasconcelos THC, Vianna RPT. Prevalence and anthropometric predictors of high blood pressure in schoolchildren from João Pessoa - PB, Brazil. Arq Bras Cardiol. 2010; 95(5):629-34.

27. Gomes BMR, Alves JGB. Prevalência de hipertensão arterial e fatores associados em estudantes de Ensino Médio de escolas públicas da região metropolitana do Recife, Pernambuco, Brasil, 2006. Cad Saúde Pública 2009; 25(2):375-81.

28. Rezende DF, Scarpelli RAB, Souza GF, Costa JO, Scarpelli AMB, Scarpelli $\mathrm{PA}$, et al. Prevalência da hipertensão arterial sistêmica em escolares de 7 a 14 anos do Município de Barbacena, Minas Gerais, em 1999. Arq Bras Cardiol. 2003; 81(4):375-80. 
29. Nogueira PCK, Costa RF, Cunha JSN, Silvestrini L, Fisberg M. Pressão arterial elevada em escolares de Santos: relação com a obesidade. Rev Assoc Med Bras. 2007; 53(5):426-32.

30. Crispin PAA, Peixoto MRG, Jardim PCBV. Risk factors associated with high blood pressure in two-to five-year-old children. Arq Bras Cardiol. 2014; 102(1):39-46.

31. Muntner P, He J, Cutler JA, Wildman RP, Whelton PK. Trends in blood pressure among children and adolescents. JAMA. 2004; 291(17):2107-13.

32. Rosaneli CF, Baena CP, Auler F, Nakashima ATA, Netto-Oliveira ER, Oliveira $\mathrm{AB}$, et al. Aumento da pressão arterial e obesidade na infância: uma avaliação transversal de 4.609 escolares. Arq Bras Cardiol. 2014; 103(3):238-44.
33. Brasil. Ministério da Saúde. Guia alimentar para a população brasileira [Internet]. 2014 [cited 2016 Apr 21]. Available from: http://189.28.128.100/ dab/docs/portaldab/publicacoes/guia_alimentar_populacao_brasileira.pdf.

34. Nobre LN, Lessa AD. Influence of breastfeeding in the first months of life on blood pressure levels of preschool children. J Pediatr (Rio J). 2016; 92(6):588-94.

35. Jornayvaz F, Vollenweider P, Bochud M, Mooser V, Waeber G, Marques-Vidal P. Low birth weight leads to obesity, diabetes and increased leptin levels in adults: the CoLaus study. Cardiovasc Diabetol. 2016; 15(73):1-10.

36. Yu ZB, Han SP, Zhu GZ, Zhu C, Wang XJ, Cao XG, et al. Birth weight and subsequent risk of obesity: a systematic review and meta-analysis. Obes Rev. 2011; 12(7):525-42 